\title{
Incumbents Beware: The Impact of Offshoring on Elections
}

\author{
Stephanie J. Rickard \\ Department of Government, London School of Economics and Politics, London, UK \\ E-mail: s.rickard@lse.ac.uk
}

(Received 21 February 2020; revised 6 August 2020; accepted 4 November 2020; first published online 5 March 2021)

How does globalization affect politics? One of the most controversial aspects of globalization is offshoring, when manufacturing operations and business functions move abroad. Although voters generally dislike offshoring, it remains unclear how moving jobs abroad impacts democratic elections. Using a difference-in-differences estimation strategy, the author finds that incumbent government parties lose more votes in municipalities where a local plant moved production abroad between elections than in municipalities that did not experience such an event. The result holds across various time periods, different incumbent parties and diverse types of elections. In both national and regional elections, voters punish incumbent government parties when a local firm moves production abroad. Incumbent parties' vote shares fall as the number of jobs lost due to offshoring increases. In multiparty governments, voters disproportionately punish the largest coalition party for offshoring. The results of an original survey administered in Spain verify the importance of offshoring for voters' retrospective evaluations of incumbents.

Keywords: globalization; offshoring; voting; coalition government; incumbents; economic vote; regional government; elections

How does globalization affect politics? One of the most salient aspects of modern-day globalization is offshoring, when firms move their manufacturing operations or business functions abroad. ${ }^{1}$ When asked what globalization brings to mind, 45 per cent of European respondents said they think about the offshoring of jobs to countries with cheap labor. ${ }^{2}$ Despite offshoring's salience to voters, it remains unclear how this controversial facet of globalization impacts democratic politics. In this study, I investigate how offshoring influences both national and regional elections.

Voters generally dislike offshoring: 95 per cent of US respondents oppose businesses' decisions to move manufacturing operations abroad (Mansfield and Mutz 2013). Voters may dislike the practice because of its negative economic consequences. When firms relocate production abroad, people lose their jobs. Workers laid off because of offshoring experience significant economic hardships (for example, Bachmann and Braun 2011; Görg and Hanley 2005; OECD 2007). Offshored workers tend to have different age and skill profiles than other unemployed persons, and these characteristics lower their chances of obtaining new jobs under similar conditions (Miguélez Lobo 2004). Beyond individuals directly impacted by a plant closure, offshoring also entails negative economic consequences for the local community. When a local factory closes to move production abroad, workers in auxiliary companies and local suppliers may also be

\footnotetext{
${ }^{1}$ The academic literature primarily deals with two notions of offshoring (Jensen, Quinn and Weymouth 2017). The first refers to moving certain tasks in the production process overseas. The second (which I focus on here) is when a company relocates production abroad to gain a comparative advantage.

${ }^{2}$ European Commission (2005) Eurobarometer 63, question Q6.

( ) The Author(s) 2021. Published by Cambridge University Press. This is an Open Access article, distributed under the terms of the Creative Commons Attribution licence (http://creativecommons.org/licenses/by/4.0/), which permits unrestricted re-use, distribution, and reproduction in any medium, provided the original work is properly cited.
} 
laid off. Wages in the local economy subsequently fall as jobs become scarcer; as a result, local real estate values decrease, young people leave the area and social services decline (for example, Frieden 2018; OECD 2007).

Although voters generally dislike offshoring, it is unclear - from a theoretical perspective what effect it may have on voting behavior. A sizable literature on retrospective voting documents a pattern, at the aggregate level, whereby voters tend to punish the incumbent for poor national economic performance during their time in office (for example, Anderson 2007; Lewis-Beck and Stegmaier 2000). However, we know relatively little about the extent to which the personal experience of a local economic shock brings about an anti-incumbent vote (Margalit 2019, 287). When voters experience a negative economic shock because of offshoring, they may vote against the incumbent in the subsequent election.

However, offshoring may have no effect on voters' choice at the ballot box. Voters may see offshoring as an inevitable consequence of globalization - one over which the government has little influence. If voters believe governments in a highly globalized world have a limited ability to sway firms' decisions about production locations, they may discount or even ignore offshoring events in their retrospective evaluations of incumbents. The high level of international economic integration that makes offshoring possible may also reduce the importance of economic-based issues, such as offshoring, for voters' decisions at the ballot box by reducing governments' perceived 'room to maneuver' (for example, Hellwig 2001; Hellwig 2014; Samuels and Hellwig 2010). ${ }^{3}$

Precisely how offshoring affects democratic elections is ultimately an empirical question. I address this question here in one of the first studies to directly measure offshoring and its electoral consequences. I find that voters punish incumbents for local offshoring events. Using a difference-in-differences estimation strategy, I show that incumbent government parties lose more votes in municipalities where local production moved abroad between elections than in those that did not experience such an event. This result holds for elections in various years $(2000,2003,2004,2006,2008,2011)$, for different incumbent parties (that is, socialist and centerright parties) and for different levels of government. In both national and regional elections, voters punish incumbent government parties for offshoring, and parties' vote shares fall as the number of jobs lost due to offshoring increases. Voters punish parties from both the left and the right of the ideological spectrum for offshoring. In multiparty coalition governments, voters disproportionately punish the largest party for offshoring. An original survey verifies the importance of offshoring for voters' decisions at the ballot box.

This study makes three contributions. First, it examines the impact of an important facet of globalization on elections in a context other than the United States. This is noteworthy because most evidence connecting globalization to democratic elections comes from the United States (for example Dorn et al. (2020); Feigenbaum and Hall 2015; Healy and Malhotra 2013; Jensen, Quinn and Weymouth 2017; Margalit 2011; Margalit 2019). However, results from the United States may not generalize to countries with different electoral institutions. America's institutions, which include plurality electoral rules and single-member districts, maximize leaders' accountability to voters (Lijphart 1984; Lijphart 2012). Accountability exists when there is clarity of responsibility for political outcomes, and voters can effectively sanction those responsible for the outcomes (Powell 2000). Plurality electoral systems tend to score highly on these criteria. It is therefore unsurprising that previous studies conducted in the United States find evidence that voters punish incumbents for negative economic shocks. Observing similar behavior in a country with different electoral institutions is more unexpected.

Voters in countries with proportional electoral rules find it more difficult to hold elected leaders accountable for negative economic shocks. Proportional representation (PR) prioritizes representation over accountability. There is relatively less clarity of responsibility for political

\footnotetext{
${ }^{3}$ See Kayser (2007) for a comprehensive discussion of this literature.
} 
outcomes, and voters find it more difficult to effectively sanction those responsible for the outcomes in PR systems (for example, Lijphart 1984; Lijphart 2012; Powell 2000). In PR systems with closed-party lists, for example, voters can only cast their vote for a political party; they cannot vote for an individual candidate. As a result, voters cannot punish individual parliamentary representative(s) from their own district when a local plant closes to move abroad. Because some countries' electoral institutions make it more difficult for voters to hold leaders accountable for economic shocks, globalization may have different electoral impacts in different countries.

I investigate how offshoring impacts elections in Spain - a country with proportional electoral rules, multi-member districts and closed party lists. Because these institutions make it harder for voters to punish elected leaders for negative economic shocks, Spain is arguably a hard case in which to find an impact of offshoring on elections. ${ }^{4}$ Yet, I find evidence that Spanish voters punish incumbent government parties for offshoring. They do so even when faced with a multiparty coalition government, which increases the difficulty of assigning blame for negative economic shocks (Duch and Stevenson 2013).

These results show that the electoral consequences of globalization extend beyond the United States to countries with different electoral institutions. Even in a democracy with less majoritarian institutions than the United States, voters nevertheless hold incumbents accountable for offshoring. This is an important finding, because voters' ability and willingness to evaluate incumbents' performance at the ballot box plays a key role in democratic accountability (for example, Ashworth 2012; Besley 2006).

Secondly, this study contributes new evidence to understanding how globalization affects voter behavior in multilevel polities. Most previous studies focus exclusively on globalization's impact on national elections (for example Autor et al. 2016; Jensen, Quinn, and Weymouth 2017). ${ }^{5}$ In contrast, I investigate both national and regional elections. I find novel evidence that voters punish incumbent parties for offshoring in both regional and national elections. This finding suggests that by examining only national elections, previous studies may have underestimated the total electoral impact of globalization.

Finally, this study provides novel causal evidence linking offshoring to elections. Despite the large body of scholarship on the political consequences of globalization, the impact of offshoring has remained largely unexamined to date. Previous studies focus instead on other facets of globalization, such as import shocks (for example, Autor et al. 2016; Colantone and Stanig 2018; Jensen, Quinn, and Weymouth 2017) and foreign direct investment (FDI) (for example, Owen 2018). This omission is surprising, given that offshoring is one of the most salient and controversial aspects of modern-day globalization. It is problematic because the distributional consequences of offshoring differ from those of international trade (Owen 2017); therefore, offshoring may affect voting behavior differently than import shocks.

The lack of research on offshoring's electoral effects is likely due to the difficulty of identifying offshoring events and quantifying the number of jobs lost because of firms' decisions to move production abroad. Unlike imports or FDI, there is no single authoritative source of data on offshoring. Previous studies consequently sidestep the challenge of identifying offshoring events and instead use indirect proxies. In this study, I employ novel data on offshoring events and job losses caused by offshoring. These data come from multiple, diverse sources of information and allow for a direct investigation of how actual offshoring events affect real-world voting behavior. This evidence contributes to debates at the heart of democratic representation, such as what economic outcomes voters hold politicians accountable for in an era of hyper-globalization (Rodrik 2011).

\footnotetext{
${ }^{4}$ However, see Field (2016) for an alternative perspective.

${ }^{5}$ Owen (2018) is a notable exception. In an innovative study, she examines the impact of FDI on mayoral elections in Brazil.
} 


\section{Connecting offshoring to voting}

Surveys show that voters generally dislike offshoring (for example, Mansfield and Mutz 2013). But how does offshoring influence their decisions at the ballot box? I contend there are several reasons why a local offshoring event may engender an anti-incumbent vote. First, offshoring entails real economic costs. When firms relocate their production abroad, people lose their jobs. Workers laid off because of offshoring experience a deterioration in their personal economic circumstances (for example, Bachmann and Braun 2011; Görg and Hanley 2005; OECD 2007). Offshored workers tend to have different age and skill profiles than other unemployed persons, and these characteristics lower their chances of obtaining new jobs under similar conditions (Koeber and Wright 2001). In Spain, for example, workers fired because of offshoring tend to be middle aged (Miguélez Lobo 2004). For them, the possibility of retraining to obtain jobs under similar conditions is relatively limited. As a result, many workers made redundant by offshoring end up accepting worse pay and/or temporary jobs (Miguélez Lobo 2004) - often causing significant losses in real earnings (Michael and Michael 2012). Voters whose real earnings decline because of offshoring may subsequently vote against the incumbent as a result of 'pocketbook' considerations.

The negative pocketbook effects of offshoring extend beyond the workers at the affected plant. When firms move production abroad, workers employed at auxiliary companies and local suppliers, some of which will be losing their main customer, may also be laid off. For example, the offshoring of production from Braun's plant in Esplugues de Llobregat, Spain to China resulted in 690 direct job losses. But estimates suggest that the move resulted in the elimination of a further 1,500 jobs connected to Braun's plant via its network of local providers and other services. ${ }^{6}$ These 1,500 jobs were cut as an indirect consequence of offshoring, but the workers who were fired nevertheless experienced real earning losses as a result. These workers may vote against the incumbent government party in the next election as a result of offshoring's indirect pocketbook effects.

Direct and indirect job losses from offshoring negatively impact the local community. When factories that used to provide decent paying jobs move abroad and local suppliers reduce their work force, wages in the local labor market fall (Ebenstein et al. 2014; Hummels et al. 2014). As jobs become scarcer, unemployment rises and mobile inhabitants leave the area in search of better wages and employment opportunities (Amiti and Wei 2009; Biscourp and Kramarz 2007). Over time, local income and property values fall, which leads to a decline in local government tax revenue and a deterioration of local public services (Feler and Senses 2017). The erosion of a community's economic base may also have negative social effects, including a rise in alcoholism and opioid abuse (Dean and Kimmel 2019; Eisen et al. 2020; Frieden 2018).

Given the negative impact of offshoring on the local area, people in the affected community may vote against the incumbent government following a local offshoring event. ${ }^{7}$ They may do so either because: (1) their own economic fortunes decline along with the region's or as a result of (2) local sociotropism. Local sociotropism refers to the idea that voters are concerned about the economic well-being of their community and not simply their own personal financial situation (for example, Alkon 2017; Kiewiet and Lewis-Beck 2011). Research shows that voters often consider the interests of others when formulating their attitudes about economic policies and the governments responsible for them (for example, Lü, Scheve and Slaughter 2012; Mansfield and Mutz 2009; Mansfield and Mutz 2013). Individuals predominantly care about the well-being of those closest to them, including their family, neighbors and local community. Because

\footnotetext{
${ }^{6}$ https://elpais.com/diario/2006/05/20/economia/1148076003_850215.html.

${ }^{7}$ Although I focus here on the negative economic impacts of offshoring on local communities, offshoring may have varied effects at the individual level. While some individuals suffer economic losses as a result of offshoring, others in the same country may gain economically, particularly in the long run. Exactly who wins and loses from offshoring at the individual level is the subject of a growing body of research. See, for example, Owen (2017) and Owen and Johnston (2017).
} 
individuals have a social, material and psychological stake in their communities (for example, Ansolabehere, Meredith and Snowberg 2014; Kiewiet and Lewis-Beck 2011), the closure of a local firm to move abroad, and its knock-on effects for the surrounding area, may influence peoples' voting behavior. In a community hit by offshoring, people may cast an anti-incumbent vote out of a sense of 'place-based' threat - even if the voter herself is not personally hurt by offshoring (Cramer 2016).

The local sociotropism mechanism requires that voters not directly affected by a plant closure nevertheless know about it. Knowledge of offshoring appears to be relatively widespread. In Spain, for example, 41 per cent of respondents in an original survey of a nationally representative sample said they knew someone personally who had lost their job because a business had closed to move abroad. ${ }^{8}$ And 32 per cent said they had heard about a business in their local area moving abroad.

Knowledge of offshoring events may be relatively common, because firms' decisions to move production abroad are often reported in the media; in Spain, these reports frequently trigger public protests. In early 2002, for example, the US-owned multinational, Lear, announced the closure of its electrical components plant in Cervera, Spain. The announcement led to protests attended by over 4,000 people including the plant's workforce of 1,200 employees and local trade union members (Miguélez Lobo 2004). Similarly, in January 2003, more than 2,000 people protested the offshoring of production from the Moulinex factory in Barbastro, Spain to China, which resulted in 150 job losses. ${ }^{9}$

This is not to suggest that informed but personally unaffected voters have a sophisticated model of the distributional impact of offshoring. It is simply to propose that voters typically know when their communities are doing poorly and that offshoring probably played some role in the problem (Frieden 2018). Both personal pocketbook considerations and sociotropic attitudes may lead voters to cast an anti-incumbent vote following a local offshoring event.

The extent of the anti-incumbent vote will depend on how much blame voters attribute to the government for offshoring. Voters may believe governments can keep firms onshore by providing subsidies and/or tax breaks. Elected leaders often espouse this view, using the threat of offshoring to justify generous subsidies and tax incentives for firms (Jofre-Monseny, Sánchez-Vidal and Viladecans-Marsal 2018). Voters may observe governments providing firms with economic incentives and firms subsequently deciding to stay in the country. In Spain, for example, voters saw the government provide lucrative subsidies to the Seat and Ford automotive plants in Barcelona and Valencia, respectively, to keep them onshore (Jofre-Monseny, Sánchez-Vidal and Viladecans-Marsal 2018). Voters may have thus concluded that governments can keep firms onshore by providing them with sufficient economic incentives. If voters believe government action can avert offshoring, they may punish incumbents for their perceived inaction when they observe a local plant moving production abroad.

In contrast, if voters think governments have little influence over firms' location decisions, they may not hold incumbents responsible for offshoring. Voters may believe offshoring is an inevitable consequence of globalization - over which the government has little control. Offshoring occurs precisely when levels of international economic integration are high. High levels of integration reduce governments' room to maneuver in policy making, and prior research suggests that voters recognize the constraints that globalization imposes on governments (for example, Hellwig 2001; Hellwig 2014; Kayser 2007; Samuels and Hellwig 2010). Voters in countries with very open economies tend to hold their governments less responsible for the nation's economic performance, for example (for example, Hellwig 2001; Hellwig 2014; Kayser 2007; Samuels

\footnotetext{
${ }^{8}$ The survey was administered online to 1,000 respondents by Netquest in October 2018 . The sample was selected using age, gender and province quotas to ensure a nationally representative sample. The exact survey questions (in English) are provided in the Appendix.

${ }^{9}$ https://www.diariocordoba.com/noticias/economia/rechazo-ajuste-empleo-moulinex_37789.html.
} 
and Hellwig 2010). If voters believe that governments in a highly globalized world have little ability to sway firms' decisions about production locations, they may discount or even ignore offshoring in their retrospective evaluations of incumbents.

\section{Research design}

Taken together, these mechanisms suggest a testable hypothesis: areas that experience a local offshoring event will return fewer votes for the incumbent government party in the subsequent election than areas that did not experience an offshoring event.

I test this hypothesis using evidence from Spain. Spain experienced a wave of offshoring beginning in the early 2000s. During this period, the Spanish economy was strong. It grew at 4 per cent per year on average from 2000-2006 and enjoyed lower unemployment rates than other European countries (OECD 2007).

The surge of offshoring in Spain occurred for two main reasons. First, the pending expansion of the European Union (EU) would bring ten new countries into the EU in 2004. Many of the new member states had lower labor costs than Spain which, during this period, had neither very low pay nor very high innovation. In 2004, the average annual earnings per worker in Spain was USD 17,547, compared to just USD 5,513 in Poland. Spain's wage levels and intermediate position in the global division of labor led firms to move their manufacturing operations abroad. The Spanish automobile components sector, for example, lost 20 per cent of its workforce to central and eastern European countries between 2002 and 2005 (Miguélez Lobo 2004).

Secondly, the strength of Spain's economy during the early 2000s made it relatively less attractive to cost-conscious firms. Because firms' location decisions are driven primarily by production costs (for example, Helpman 1984; OECD 2007), they have incentives to leave a country when its economy is doing well. Wages and rents tend to rise in growing economies, which makes the country less attractive as a place of production. Companies may subsequently consider moving production to a lower-cost country precisely when their host country's economy is growing strongly. For example, the Danish firm Vestas decided to close its plant in the Spanish municipality of León, which produced wind turbines for the global market, and relocate production to China to save money on labor and other production costs.

\section{Data}

I identify manufacturing-sector offshoring events that occurred in Spain from 2000 to $2011 .^{10}$ These novel data represent one of the few attempts to directly measure offshoring. Previous studies sidestep the challenge of identifying offshoring events and instead adopt one of two strategies. ${ }^{11}$ First, some studies have assumed that individuals with certain occupations or skills face a higher risk of seeing their jobs offshored (for example, Chase 2008; Owen 2017; Owen and Johnston 2017; Rommel and Walter 2018). While innovative, these occupational- and skillbased measures indicate only the number of potential job losses rather than the number of actual jobs lost due to offshoring. As such, these measures are unsuitable for investigating how the experience of a local offshoring event affects politics.

A second, frequently employed strategy is to investigate public opinion data. Using survey data, prior studies have examined how respondents perceive offshoring (Mansfield and Mutz 2013) and how vulnerability to offshoring correlates with expressed trade policy preferences (Owen and Johnston 2017) and self-reported political party preferences (Rommel and Walter 2018). While these studies are valuable, it remains largely unknown how self-reported preferences translate into actual voting behavior (Margalit 2013; Margalit 2019). As such, knowing the effects of offshoring - or more precisely, the risk of offshoring - on preferences may not be particularly

\footnotetext{
${ }^{10}$ During this period, offshoring in Spain was largely concentrated in manufacturing (OECD 2007).

${ }^{11}$ For a notable exception, however, see Margalit (2011).
} 
helpful for explaining actual voting behavior. Margalit (2013), for example, finds that economic shocks have a strong impact on attitudes towards welfare spending but no effect on actual voting behavior. It is therefore important to investigate the impact of genuine offshoring events on realworld voting behavior.

To do this, I collected data on offshoring events in Spain using multiple sources. I build on Jofre-Monseny, Sánchez-Vidal and Viladecans-Marsal (2018), who use data from Myro-Sánchez and Fernández-Otheo (2008) and balance sheet data from the Sistema de Análisis de Balances Ibéricos (SABI) to identify offshoring events. I confirm the details of each of these offshoring events using Spanish newspapers, data from Bronfenbrenner and Luce (2004), and data from the European Restructuring Monitor. I include an offshoring event in my dataset only if the details of the event are confirmed by at least two sources. For each offshoring event, I identify the plant's exact geographic location and record the number of jobs lost as a direct result of the move abroad.

Using these novel, geo-located data, I construct two groups: (1) 'treated' municipalities that experienced job losses due to offshoring between two elections and (2) a control group that did not. In addition to this binary treatment indicator, I also construct an 'intensity of treatment' indicator that reports the number of job losses in a municipality that occurred as a direct result of offshoring between two elections.

I use municipalities as my unit of analysis because of offshoring's strong local effects. People living near a shuttered plant experience the economic fallout from offshoring (Holl 2004). Some people in the local area lose their jobs directly as a result of production moving abroad. Others lose their jobs indirectly. And when local factories that used to provide decent paying jobs move production abroad, the surrounding areas experience increased unemployment, lower labor force participation and outmigration by mobile inhabitants (Broz, Frieden and Weymouth 2019; Frieden 2018). Given its local economic impacts, offshoring's electoral consequences are most appropriately measured at the community level. For this reason, my unit of analysis is municipalities. Spanish municipalities are relatively small; the average municipality in my sample has a population of less than 24,000 people. Additionally, municipalities broadly approximate local labor markets. Most people live and work in the same municipality. In fact, 60 per cent of the respondents in my survey reported that they worked in the same municipality in which they lived.

\section{Empirical Model}

Given the myriad possible correlates of incumbent vote shares, I use a difference-in-differences estimation strategy. The difference-in-differences estimator does not require the voting preferences in both groups of municipalities to be the same. Rather than comparing both groups directly at a particular point in time, the estimator instead compares the change in voting choices by both groups over time, which helps rule out alternative explanations. If offshoring occurs between two elections and this event influences voting decisions, a change in the voting patterns in treated municipalities will be observed but not in control municipalities.

I conduct several tests using various elections throughout the period from 2000 to 2011, including both national and regional elections. Reassuringly, the main result is consistent across all tests: incumbent government parties lose votes in areas that experienced an offshoring event relative to areas that did not. The negative effect of offshoring on incumbents' vote shares is not specific to any given election, political party or time period.

In my first test, I examine election years $t=(2000,2004)$. National parliamentary elections in these years span the early wave of offshoring and exclude the 2008 global financial crisis, which hit Spain's economy hard. But prior to the 2008 crisis, Spain enjoyed the largest period of economic growth since its democratic transition (Fernández-Albertos, Kuo and Balcells 2013). This fact helps to distinguish the effects of offshoring from poor national economic performance. 
I focus on election returns in Catalonia's 943 municipalities. Because of Spain's economic geography, most of the offshoring events took place in Catalonia. ${ }^{12}$ Catalonia is Spain's most industrial region; while all of Catalonia's municipalities experienced job losses during this period, some experienced job losses due to offshoring. In untreated municipalities, job losses were caused by factors other than offshoring, including bad management and labor market churn. Untreated municipalities are therefore most correctly described as municipalities that experienced job losses for reasons other than offshoring. Treated municipalities experienced job losses due to offshoring.

Focusing on Catalonia provides a comparison of more alike municipalities. Catalan municipalities are more similar to one another, on average, than they are to municipalities in other regions of Spain, such as Extremadura. In recent years, for example, a strong independence movement has arisen in Catalonia. While the issue of independence was not absent from politics during the study period, it was far from the most salient issue. Prior to 2006, relatively few people wanted independence for Catalonia. In 2006, just 15 per cent of Catalans supported independence (Hierro and Queralt 2021). A dramatic increase in support for independence took place after 2010 when a decision by the Spanish Constitutional Court helped to fuel the pro-independence movement (Hierro and Queralt 2021). By 2013, support for independence had risen to nearly 50 per cent (Hierro and Queralt 2021). The dramatic rise in pro-independence sentiment is one reason why my sample excludes elections after 2011. If, however, the economic vote is diluted in Catalonia by the issue of independence during my study period, it would bias against finding any systematic effect of offshoring on incumbents' vote shares. As a robustness test, I examine voting patterns across the country and find similar results, as discussed below.

For each municipality, I calculate the change in the incumbent government party's vote shares between the 2000 and 2004 elections. This electoral outcome is theoretically appropriate given Spain's closed-list elections in which voters choose a political party rather than an individual candidate at the ballot box. In the 2004 election, voters had to decide whether to vote for the incumbent government party Partido Popular (PP). PP is a center-right party that is broadly conservative in orientation; its economic policies are generally pro-market.

Let Y1it and Yoit indicate the pair of potential vote shares that the incumbent government party attains in municipality $i$ at time $t$ when exposed to the treatment or control condition between the two elections. The quantity of interest is the electoral effect of offshoring, which is defined as the average treatment effect on the treated (ATT), given by $\alpha=E[Y 1 i, t-Y 0 i, t \mid$ $D i=1]$ This measures the average difference between the post-treatment vote shares that the affected municipalities attained with and without the treatment. Since it is not possible to observe $E[Y 0 i, t \mid D i=1]$, I estimate the potential outcome based on the usual difference-in-differences assumption of parallel trends. To assess the empirical validity of the parallel-trends assumption, I examine whether the PP vote share in municipalities affected by offshoring between the 2000 and 2004 elections followed a similar trend to the control municipalities in the years prior to the treatment. The trends are, in fact, parallel, as illustrated in Appendix Figure A1. I assume $E[Y 0 i, t-Y 0 i,(t-1) \mid D i=1]=E[Y 0 i, t-Y 0 i,(t-1) \mid D i=0]$, where $t-1$ equals the year of the most recent previous election. Based on this assumption, the ATT is identified from observed outcomes as: $\alpha=(E[Y i, t \mid D i=1]-E[Y i, t-1 \mid D i=1])-(E[Y i, t \mid D i=0]-E[Y i, t-1 \mid D i=0])$.

I estimate $\alpha$ using a standard fixed effects regression given by:

$Y i t=v i+\delta t+\alpha D i t+\chi i t \beta+\varepsilon i t$ where Yit is the incumbent government party's vote share in municipality $i$ at time $\mathrm{t}, v i$ is a municipality-level fixed effect to control for any time-invariant unobserved factors, $\delta \mathrm{t}$ is a period fixed effect to control for common trends, $\alpha$ is the treatment effect, Dit is the treatment variable, and $\varepsilon$ is an idiosyncratic error term clustered by municipality. $X i t$ is a vector of time-varying covariates including a constant. I first present the main results without time-varying covariates (except a constant). I then add the following control variables,

\footnotetext{
${ }^{12}$ On the political consequences of economic geography, see Rickard $(2012,2018)$.
} 
Table 1. Effect of offshoring on incumbent vote shares, by municipality, 2000-2004

\begin{tabular}{|c|c|c|c|c|}
\hline Dependent variable $=\mathrm{PP}$ vote share & 1 & 2 & 3 & 4 \\
\hline Treatment (offshoring event) & $\begin{array}{c}-1.947 \\
(0.463)\end{array}$ & $\begin{array}{c}-1.636 \\
(0.423)\end{array}$ & $\begin{array}{c}-1.518 \\
(0.468)\end{array}$ & $\begin{array}{r}-1.340 \\
(0.540)\end{array}$ \\
\hline Post period & $\begin{array}{c}-6.131 \\
(0.121)\end{array}$ & $\begin{array}{c}-7.000 \\
(0.224)\end{array}$ & $\begin{array}{c}-6.940 \\
(0.336)\end{array}$ & $\begin{array}{r}-6.807 \\
(0.426)\end{array}$ \\
\hline Population (thousands) & & $\begin{array}{c}0.035 \\
(0.036)\end{array}$ & $\begin{array}{c}0.031 \\
(0.039)\end{array}$ & $\begin{array}{c}0.026 \\
(0.044)\end{array}$ \\
\hline Unemployment rate & & & $\begin{array}{c}-0.196 \\
(0.498)\end{array}$ & $\begin{array}{r}-0.085 \\
(0.552)\end{array}$ \\
\hline Economic growth rate & & & & $\begin{array}{c}0.040 \\
(0.025)\end{array}$ \\
\hline Intercept & $\begin{array}{c}17.372 \\
(0.060)\end{array}$ & $\begin{array}{c}20.783 \\
(0.767)\end{array}$ & $\begin{array}{c}21.323 \\
(1.722)\end{array}$ & $\begin{array}{c}20.591 \\
(1.975)\end{array}$ \\
\hline Observations & 1,885 & 378 & 378 & 333 \\
\hline$R^{2}$ & 0.736 & 0.911 & 0.911 & 0.906 \\
\hline
\end{tabular}

Note: robust standard errors in parentheses.

all of which are measured at the municipality level: population, unemployment and economic growth. The data come from the Statistical Institute of Catalonia. ${ }^{13}$

\section{Results}

Table 1 reports the difference-in-differences estimates of the electoral effect of offshoring, as measured by the change in the incumbent government party's vote shares between the 2000 and 2004 national elections. The negative coefficient on the time period variable (Post Period) demonstrates that the incumbent government party lost votes, on average, between the 2000 and 2004 elections. ${ }^{14}$ However, their losses were greater in treated municipalities.

The estimated ATT is statistically significant (with a t-statistic of 4.2) and realistic in substantive terms. Estimated treatment effects range from -1.34 to -1.95 percentage points across the four models. The largest estimated treatment effect is observed in Model 1. Model 2 introduces a measure of municipalities' population as a control variable. In Model 3, the unemployment rate is added as an additional control variable. Controlling for unemployment helps to isolate the electoral impact of jobs lost due to offshoring. Controlling for unemployment, the incumbent government party's vote shares fall in response to job losses due to offshoring. In Model 4, the economic growth rate is added. Although the addition of each control variable reduces the magnitude of the average treatment effect, the ATT remains negatively signed and statistically significant at at least the 95 per cent level in all four models. The incumbent government party's vote share fell by 1.6 percentage points in treated municipalities, on average, across all four models, which constitutes approximately a 15 per cent decrease compared to the overall PP vote share in Catalonia in 2004.

Not all offshoring events are equal; some generate more job losses than others. To address this fact, I construct an 'intensity of treatment' indicator that measures the number of jobs lost as a direct result of offshoring in a given municipality between two elections. The results are reported

\footnotetext{
${ }^{13}$ The unemployment data measure the registered number of unemployed persons as of 31 March of the reference year. I use all of the data available at the municipality level. Unfortunately, not all variables are available for all municipalities and their inclusion in the model reduces the sample size.

${ }^{14}$ This may be because three days before the 2004 election ten bombs exploded on four commuter trains heading into central Madrid. The blasts killed 191 people and injured nearly 1,800. Although this event may have affected voting in the 2004 election (Bali 2007; Montalvo 2011), it is unlikely to account for my findings, as I demonstrate in Appendix Table A1.
} 
Table 2. Effect of offshored jobs on incumbent vote shares, by municipality, 2000-2004

\begin{tabular}{lcccc}
\hline Dependent variable = PP vote share & 1 & 2 & 3 & 4 \\
\hline Intensity of treatment (\# of offshored jobs) & -0.004 & -0.003 & -0.003 & -0.003 \\
& $(0.001)$ & $(0.001)$ & $(0.001)$ & $(0.001)$ \\
Post period & -6.135 & -6.967 & -6.916 & -6.783 \\
& $(0.121)$ & $(0.224)$ & $(0.332)$ & $(0.421)$ \\
Population (thousands) & & 0.018 & 0.016 & $(0.012$ \\
& & $(0.033)$ & $(0.035)$ & $-0.040)$ \\
Unemployment rate & & & -0.173 & $(0.059)$ \\
& & & $(0.504)$ & 0.041 \\
Economic growth rate & & & $(0.025)$ \\
Intercept & 17.372 & & 21.045 \\
& $(0.060)$ & $(0.704)$ & $(1.653)$ & $(1.895)$ \\
Observations & 1,885 & 378 & 378 & 333 \\
$R^{2}$ & 0.736 & 0.911 & 0.912 & 0.906 \\
\hline
\end{tabular}

Note: robust standard errors in parentheses.

in Table 2. Offshoring events that produce more job losses have a larger reductive effect on the government party's vote share. The estimated effect of the 'intensity of treatment' indicator is statistically significant at the 99 per cent level in all models. The typical offshoring event in my sample generates 375 job losses. An offshoring event of this magnitude reduces the incumbent's vote share by 1.22 percentage points, on average. This constitutes more than a 10 per cent decrease compared to the overall PP vote share in Catalonia in 2004. This is a non-trivial outcome, particularly in a PR system in which every vote counts towards the party's share of seats in parliament. Furthermore, this result likely represents a lower-bounds estimate because the intensity of treatment indicator measures only the direct job losses from offshoring. ${ }^{15}$

\section{Lower-Bounds Estimates}

There are at least four additional reasons why the magnitude of the treatment effects reported in Tables 1 and 2 may represent lower-bounds estimates. First, if I missed any offshoring events in my coding efforts, a municipality might erroneously be included in the control group rather than the treatment group. The estimated difference between the control and treatment groups would consequently be biased downwards, underestimating the electoral effect of offshoring. Secondly, the offshoring events I analyze above occurred during a period of strong economic growth. Voters' responses to offshoring may be more negative in a less vibrant economy. Thirdly, since Spain is an EU member, the country's exposure to the global economy lies outside the national government's direct control. Thus Spanish voters may not punish incumbents as severely for offshoring as voters in other countries where governments have more authority over the national economy's openness to globalization (Hellwig 2014).

Fourthly, the economic impacts of a plant closure in one municipality may spill over into nearby municipalities, thereby reducing the estimated magnitude of the ATT. Catalonia has more than 900 municipalities; although they vary in size, they tend to be relatively small. Although municipalities' size makes them a theoretically appropriate unit of analysis, their smallness raises the possibility of spillovers. If the economic impacts of a plant closure in one municipality spill over into neighboring municipalities, then some areas included in the control group may in fact be (partially) treated, which would bias downwards any electoral effects of offshoring I identify.

\footnotetext{
${ }^{15}$ Accurately estimating the number of indirect job losses for each offshoring event is difficult and fraught with error.
} 
To test for this possibility, I identify all municipalities adjacent to the treated municipalities. Using this geographic indicator, I exclude from the control group all municipalities that share a border with a treated municipality and re-estimate the models from Table 1. These results are reported in Appendix Table A5. All of the estimated ATTs are larger when neighboring municipalities are excluded from the control group. In Model 1, the estimated treatment effect increases by 1.44 per cent. In Model 2, the ATT increases by 6.72 per cent; in Model 3 the ATT increases by 16.35 per cent and in Model 4 it increases by 24.48 per cent when treated municipalities' neighbors are excluded from the control group. These results suggest that the effects of offshoring may spill over from treated municipalities to neighboring municipalities. However, any such spillovers bias downward the estimated impact of offshoring on incumbents' vote shares.

Finally, the ATTs reported in Tables 1 and 2 may under-report voters' discontent with offshoring because incumbents take action to minimize their vote losses from offshoring. Incumbent parties that visibly fight to stop firms from moving abroad may face less of an electoral penalty for offshoring when it does occur. As Jensen and Malesky (2018) show, offering firms incentives to invest in an area can minimize the electoral costs to politicians of failing to win investment. Incentives help incumbents claim credit for investment when it does happen and reduce blame if the investment does not materialize (Jensen and Malesky 2018). Incumbents may similarly reduce the electoral costs of offshoring by offering firms incentives to stay onshore.

Anecdotal evidence shows that incumbents work hard to keep firms onshore. The Catalan government, for example, considers offshoring potential as a condition for awarding subsidies. And all regional governments meet with firms that are planning to close a plant in their jurisdiction. These meetings typically involve discussing ways to avert the closure and save jobs. In some cases, the government's efforts to keep firms onshore are successful. For instance, the Ford automotive plant in Valencia remained in Spain after receiving generous economic benefits from the regional government (Jofre-Monseny, Sánchez-Vidal and Viladecans-Marsal 2018). Economic incentives were also successful in keeping Seat's production plant in Martorell, Spain (Jofre-Monseny, Sánchez-Vidal and Viladecans-Marsal 2018). ${ }^{16}$

In other cases, however, government attempts to keep firms onshore fail. In early 2002, when the US-owned multinational, Lear, announced the closure of its electrical components plant at Cervera, the Catalan government met with the company to discuss the closure. After the meeting, a spokesperson for the Catalan government lamented that 'the decision of the company is final and the only thing that can be achieved [by the regional government] is to delay it for a few months or phase it over a relatively brief period' (Miguélez Lobo 2004). Although Lear received economic incentives from the government, including several types of tax allowances, the Cervera plant closed its doors on 31 December 2002 and moved production to Poland; 1,200 people lost their jobs as a result.

Regardless of how successful governments are at keeping firms onshore, voters may give incumbents credit for trying to keep firms in the country. By offering firms incentives, incumbents may effectively reduce the electoral penalty from offshoring. Because virtually all of the cases in my sample involved government efforts to keep firms onshore, the reported ATTs may underestimate the full extent of offshoring's impact on incumbents' vote shares.

Although the results reported in Tables 1 and 2 may represent lower-bound estimates of offshoring's impact on incumbents' vote shares, they are nevertheless politically significant. Politics often involves competition over tight margins (Margalit 2019, 290), and the effect of offshoring on the preferences of a narrow segment of voters may have an important impact on the overall electoral outcome. The political significance of offshoring may lie not in reorienting the allegiances of the general electorate, but rather in influencing the preferences of a narrow, yet potentially consequential, segment of voters.

\footnotetext{
${ }^{16}$ However, Seat ultimately decided to manufacture 10 per cent of its Ibiza model in Bratislava, Slovakia.
} 


\section{Robustness Checks}

As a robustness check, I generated two matched samples. First, I matched municipalities that experienced an offshoring event with control municipalities that had similar shares of their labor force employed in manufacturing in 1996. ${ }^{17}$ Secondly, I matched municipalities that had similar numbers of businesses in 1996. I generated ten categories for each variable that reflected the sample's deciles. I matched treated and control municipalities using these categories and restricted matches to those in the same employment category. These results are reported in Appendix Table A6.

The average treatment effect on the treated in the matched sample is statistically significant and similar in magnitude to that in the unmatched sample. This finding indicates that municipalities' different economic profiles do not account for the electoral consequences of offshoring. Comparing municipalities with similar numbers of firms and similar numbers of people employed in manufacturing, those that experienced an offshoring event display larger declines in incumbents' vote shares than those that did not experience such an event.

As a further robustness test, I move beyond Catalonia and examine voting behavior across the country. I examined incumbent government parties' vote shares in all of Spain's provinces in national parliamentary elections in years $t=(2000,2004,2008,2011)$. Provinces correspond to national electoral districts; they are larger than municipalities but smaller than regions. Catalonia, for example, contains four provinces.

As before, I use a difference-in-differences estimation strategy. I rely exclusively on the intensity of treatment indicator here because some provinces are treated multiple times - that is, they experience multiple offshoring events between elections - and this information is not captured by a dummy treatment indicator.

Voters faced different incumbent government parties in various election years. In 2004, the center-right PP party was the incumbent. In 2011, the Spanish Socialist Workers' Party (Partido Socialista Obrero Español, PSOE) was the incumbent. The difference in the incumbents' identity allows me to examine whether voters similarly punish parties from different ends of the ideological spectrum for offshoring.

Despite the two parties' different ideological positions, voters punished both for offshoring, as reported in Appendix Table A7. PSOE's vote share fell between the 2008 and 2011 elections; in 2011, the party suffered its worst electoral defeat to date (Fernández-Albertos, Kuo and Balcells 2013). However, its losses were greater in provinces where offshoring occurred. ${ }^{18}$ The PP's vote losses were also greater in provinces where offshoring occurred. For both incumbent parties, offshoring events that produced more job losses generated greater reductions in their vote shares.

These results demonstrate that the Catalan findings generalize beyond the region. Voters who experienced a local offshoring event are more inclined to vote against the incumbent government party, irrespective of its identity (Anderson 2007).

\section{Regional elections}

Voters appear to blame the national government for local offshoring events. Do they also blame regional governments? In the devolved autonomous regions of Spain, voters elect sub-national governments that have decision-making powers over a range of policy areas. Given these powers, voters may blame regional governments for local offshoring events, in addition to the national government.

\footnotetext{
${ }^{17}$ This year is the nearest pre-treatment year for which data are available at the municipal level.

${ }^{18}$ To assess the empirical validity of the parallel-trends assumption, I examine whether the PSOE vote share in municipalities affected by offshoring between the 2004 and 2008 elections followed a similar trend to the control municipalities in the years prior to the treatment. Reassuringly, trends in the PSOE party's vote shares prior to 2008 are strikingly parallel in treated and untreated municipalities, as illustrated in Appendix Figure A2.
} 
Regional governments serve as the first line of defense for workers facing dismissal due to offshoring. Spanish labor law requires companies to inform the regional government of any plans to collectively dismiss workers at a plant in the region. After receiving such a notification, members of the regional government meet with representatives from the firm, often with the aim of minimizing the number of job losses. Given the involvement of regional governments in discussions about firms' potential moves abroad, voters may subsequently blame them when offshoring does occur.

Additionally, regional governments have decision-making powers over a range of relevant policy areas (León 2014). For example, they have considerable power over taxes, expenditures and active labor market policies (León 2014; Queralt 2012). Using these powers, regional governments could provide incentives to keep firms onshore. Voters may consequently view regional governments as being at least partially responsible for the relocation of production, and consequently jobs, abroad.

Although regional elections in Catalonia are held using the same electoral rules as national elections, regional elections typically take place in different years and turnout rates are generally lower (Riera 2013). Dual voting is also common - that is, people vote for different parties in national and regional elections (León 2014; Riera 2013). As a result, the patterns observed in national elections may not emerge in regional elections.

Additionally, the composition of the regional government in Catalonia during the period under investigation differed from that of the national government, which included only a single political party. In contrast, the regional government consisted of three parties. The Catalan Socialists Party (PSC) obtained the largest number of votes, but not seats, in the 2003 regional parliamentary election. In order to govern, it formed a coalition with two other parties: the Initiative for Catalonia-Greens (ICV) - the Catalan version of the national United Left party and the Republican Left of Catalonia (ERC), a nationalist party that advocates independence for Catalonia.

The presence of multiple parties in the regional government blurs the lines of responsibility. If citizens are to cast an 'economic vote', they must have 'clarity of responsibilities' in terms of which party is responsible for the relevant policy area (Powell and Whitten 1993). Voters generally find it easiest to allocate blame for bad economic outcomes when a single party governs (Powell 2000; Samuels and Hellwig 2010). Faced with a multiparty coalition government, voters often have difficulty allocating blame (Hobolt, Tilley, and Banducci 2013; Powell and Whitten 1993). Consequently, the deleterious effects of offshoring on incumbent government parties' vote shares may not materialize in multiparty governments.

To test this hypothesis, I again use a difference-in-differences estimation strategy. I consider regional parliamentary elections in Catalonia in years $t=(2003,2006)$. These elections occurred during Spain's offshoring surge and predate the 2008 economic crisis, as well as the dramatic rise in public support for independence and secessionist parties in Catalonia, which began in earnest after 2010. The outcome of interest is the change in the incumbent government party's vote share. More precisely, let Ydit denote potential outcomes, where Y1it and Y0it indicate the pair of potential vote shares that the party attains in municipality $i$ at time $t$ when exposed to the treatment or control condition between the two elections. Because there are three incumbent government parties, there are three pairs of Y1it and Yoit. ${ }^{19}$ Following Duch and Stevenson (2008), I estimate the three parties' vote pairs separately. The full results are reported in Appendix

\footnotetext{
${ }^{19}$ In May 2006, the ERC left the government coalition over disagreements about the final draft of changes to the region's constitution. Its withdrawal left the government without a majority and forced the regional president to call an early election. Although the ERC left the coalition, I code it as being an incumbent government party for three reasons. First, it had been in government since 2003. Secondly, the coalition ceased to govern after the ERC left. Thirdly, voters likely considered the ERC as part of the incumbent government even after its departure.
} 


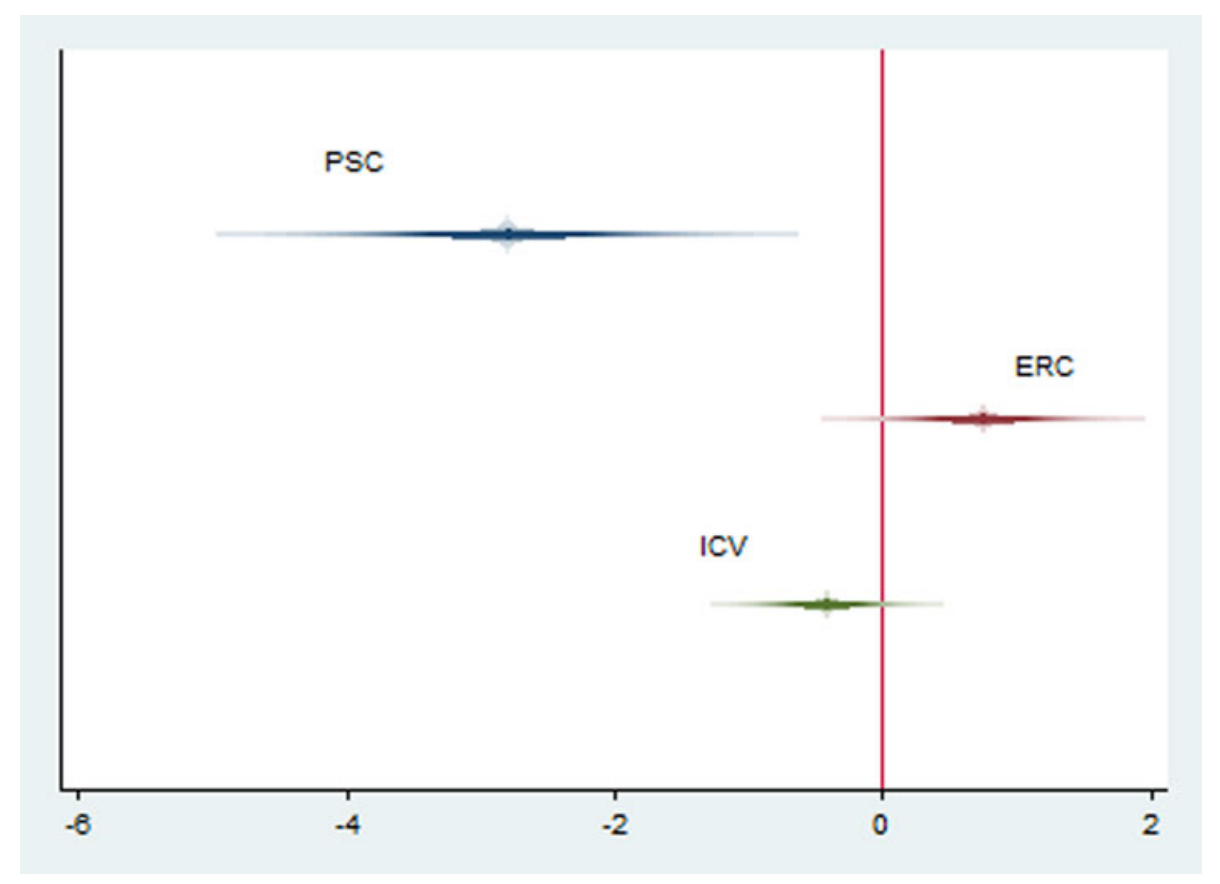

Figure 1. Effect of offshoring on regional government parties' vote shares, by municipality, 2003-2006

Tables A2, A3 and A4. The estimated ATTs from Model 1 for all three parties are displayed in Figure 1 with 99 per cent confidence intervals.

As illustrated in Figure 1, voters punished the largest coalition party, the PSC, most severely for offshoring. While the PSC's overall vote share fell between the 2003 and 2006 elections, it fell by more in treated municipalities. ${ }^{20}$ The average treatment effect for the PSC ranges from -1.7 to -2.8 percentage points across the four estimated models. ${ }^{21}$ Note that this effect is generally larger than the estimated effect of offshoring on national governments. The national PP party's vote share fell by just 1.6 percentage points in treated municipalities, on average, as reported in Table 1.

A similar pattern emerges for the intensity of treatment indicator, which measures the number of jobs lost as a direct result of a local offshoring event. The coefficient on the intensity of treatment indicator is larger for the regional party, PSC, than either of the national government parties (PSOE and PP). For national parties, the magnitude of the effect of a single job loss from offshoring in a treated municipality ranges from -0.002 to -0.004 percentage points. The effect is nearly twice as large for the regional PSC party; it ranges from -0.007 to $-0.011{ }^{22}$ These results suggest

\footnotetext{
${ }^{20}$ To assess the empirical validity of the parallel-trends assumption, I examine whether the parties' vote share in municipalities affected by offshoring between the 2003 and 2006 elections followed a similar trend to the control municipalities in the years prior to the treatment. Trends in the PSC's vote shares prior to 2006 are relatively parallel in treated and untreated municipalities, as illustrated in Appendix Figure A3.

${ }^{21}$ The first model excludes time-varying covariates (except a constant). The second model includes a control for municipalities' population. In Model 3, municipalities' unemployment rate is included as an additional control variable. Although unemployment does not have a robust effect on incumbent vote shares, offshoring events that generate job losses do. Higher economic growth rates correlate with higher vote shares for the PSC, as illustrated in Model 4. The addition of each control variable reduces the magnitude of the ATT but it remains negatively signed and statistically significant at conventional levels across all models.

${ }^{22}$ The estimated coefficient on the intensity of treatment indicator is negatively signed and statistically significant at the 95 per cent level in all models.
} 
that voters attribute more blame for local offshoring events to regional governments than national governments.

Of the three parties in the regional government, voters punished the PSC most severely for offshoring. A loss of 250 jobs due to offshoring reduced the PSC's vote share by 2 percentage points in treated municipalities, on average. ${ }^{23}$ In contrast, 250 offshored jobs reduced the ICV party's vote share by just 0.5 percentage points. Unlike its coalition partners, the ICV's vote shares grew, on average, between the 2003 and 2006 regional elections. ${ }^{24}$ Although the ICV's vote shares increased overall, the party did relatively less well in municipalities that experienced offshoring. All but one of the ATTs is negative and statistically significant at conventional levels. However, the magnitude of the ICV's losses was smaller than the PSC's losses. The average treatment effect on the ICV's vote shares ranged from -0.41 to -0.75 percentage points across the four estimated models, which is just one-quarter of the estimated effect of offshoring on the PSC's vote share.

Job losses from offshoring had no robust effect on the ERC party's vote shares. On average, the ERC party lost votes between the 2003 and 2006 elections. However, its losses were similar in treated and control municipalities. None of the estimated ATTs was statistically significant at conventional levels. Offshoring may have had little impact on this coalition party's vote shares because it focuses on Catalan independence. Voters who support Catalan independence may do so for non-material reasons, such as identity (for example, Rodon and Guinjoan 2018); thus they may vote for pro-independence political parties like the ERC irrespective of local economic shocks.

The varied effects of offshoring on the regional parties' vote shares are consistent with theories of economic voting in coalition government. These theories were primarily developed and tested at the national level. In national elections, not all parties in a multiparty government are expected to share the same electoral fate (Martin 2018). Instead, the largest party in government is generally believed to be held the most to account for poor economic outcomes (Fortunato and Stevenson 2013; Kayser and Peress 2012). In this sub-national context, Catalan voters punished the largest coalition party in the regional government for local job losses due to offshoring. From 2003-2006, the PSC held the chief executive position and occupied the most cabinet portfolios. It also controlled the Treasury Department, which oversees subsidies and tax incentives for firms. Thus the PSC arguably had the greatest ability to keep firms onshore, which may help to explain why voters punished it most severely for offshoring.

These novel sub-national results make an important contribution to understanding how globalization affects elections at different levels of government. The sub-national results contribute to the literature on dual accountability (Rodden and Wibbels 2011), as well as the clarity of responsibility literature, which argues that economic voting is conditional on voters' ability to assign blame. In this case, voters assigned blame for offshoring to the largest coalition party, which had the greatest influence over potentially relevant policies, including subsidies and tax incentives.

\section{Descriptive survey evidence}

The difference-in-differences results suggest a causal relationship exists between offshoring and voting behavior. To probe the plausibility of these results, I fielded a nationwide survey in Spain in October 2018. The survey was administered to 1,000 respondents by Netquest using an online commercial panel. ${ }^{25}$ The sample was selected using age, gender and province quotas to ensure a nationally representative sample of respondents.

\footnotetext{
${ }^{23}$ The sample's mean number of job losses is 250 .

${ }^{24}$ Minor coalition parties like the ICV can sometimes increase their vote share when that of the larger coalition parties declines (Duch and Stevenson 2013; Fortunato and Stevenson 2013).

${ }^{25}$ Netquest is certified by ISO 26362 standards for online access panels. See the Appendix for the survey questions in English.
} 


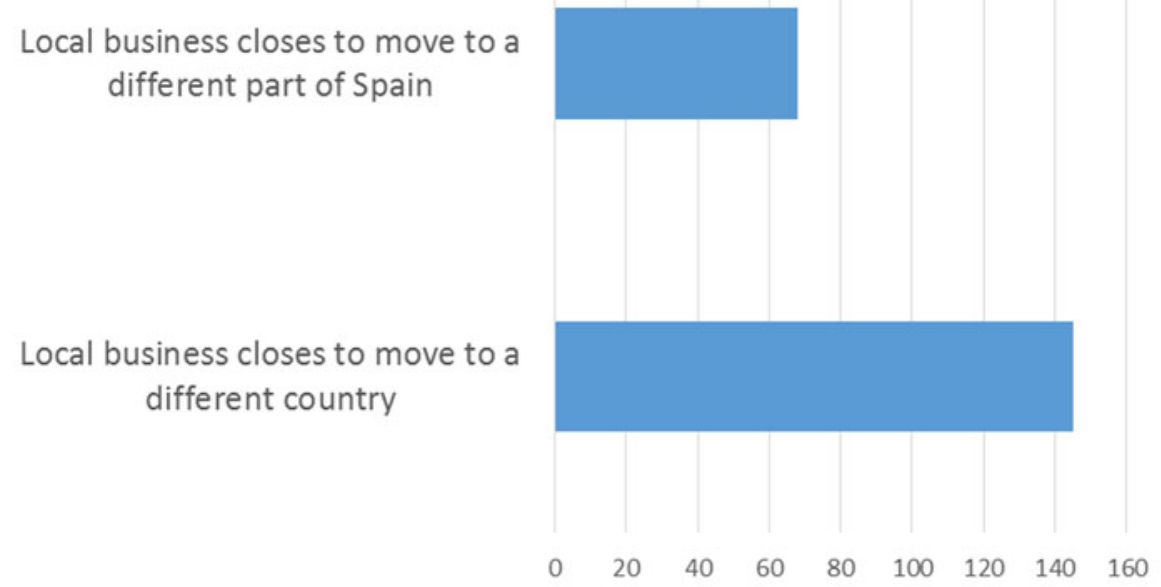

Figure 2. Which event would make you less likely to vote for the incumbent?

According to 22 per cent of respondents, the regional government deserves 'a great deal of blame' for offshoring. One-quarter said the national government deserves 'a great deal of blame' for offshoring, while 54 per cent asserted that offshoring would make them less likely to vote for the incumbent government party in the next national election. ${ }^{26}$ One in three respondents said they would be much less likely to vote for the national government party if a business in their local area closed to move abroad and the closure of this business resulted in job losses. In short, the survey results illustrate that many voters do blame incumbents for offshoring, and that local offshoring events may influence their vote choice in subsequent elections.

Twice as many respondents identified offshoring as an event that would make them less likely to vote for the incumbent government party than the closure of a local business to move to a different part of Spain, as illustrated in Figure 2. ${ }^{27}$ This finding is consistent with the difference-in-differences results reported above. Recall that changes in vote shares over time are compared across two groups of municipalities: (1) treated municipalities that experienced job losses due to offshoring and (2) control municipalities that experienced job losses for other reasons. The results suggest that voters punish incumbents more severely for job losses that occurred because of offshoring than job losses that happened for other reasons.

\section{Is offshoring different?}

When comparing voters' reactions to different types of job losses, it is important to take governments' policy responses into account. Governments may respond differently to different types of job losses. Job losses as a result of maleficence or bankruptcy, for example, may elicit a different government reaction than those due to globalization. In the United States, for instance, the government provides additional economic assistance to workers who lose their jobs because of globalization via the Trade Adjustment Assistance program. This supplementary aid is available only to workers who lost their jobs because of globalization and not for any other reason. If

\footnotetext{
${ }^{26}$ Unfortunately, the survey did not include the equivalent question for the regional government incumbent party due to budget constraints.

${ }^{27}$ See the Appendix for the exact survey question (in English) and all available answers. The most common response, chosen by 49 per cent of respondents, was 'none of the above'.
} 
governments' policy responses vary according to the source of the job losses, then comparing voters' reactions to different types of job losses may capture their reactions to government policy rather than the cause of the job loss per se.

To avoid this pitfall and further investigate the possibility that voters respond differently to offshored jobs, I conducted an additional difference-in-differences estimation using only job losses that elicited identical government responses. To do this, I compiled new data from Spain's applications to the European Globalization Adjustment Fund (EGF). The EGF is run by the European Commission and provides funding to help EU member states assist unemployed persons. It became operational in 2007 and initially funded programs to assist workers displaced as a result of globalization, defined as a substantial increase in imports, a serious shift in the trade of goods or services, a rapid decline of market share in a given sector, or the offshoring of activities. In 2008, the eligibility criteria were expanded to include redundancies resulting from the global economic crisis.

Using these data, I hold constant the government's policy responses to job losses from varied sources. In reaction to all of these job losses, the Spanish government: (1) applied for and received EU funds to help the displaced workers and (2) contributed additional funds from the national budget to assist unemployed persons. As a result, any observed changes in vote shares can be attributed to the job losses themselves rather than to any government (in)action. Additionally, these data allow me to compare voters' responses to offshoring-induced job losses and job losses from other international sources, such as foreign imports and the 2008 global financial crisis. This comparison helps isolate the impact of offshoring from voters' more general concerns about globalization.

I identified and geo-located jobs lost due to offshoring and jobs lost for other reasons using information from Spain's applications for EGF funds and related European Commission documents, which specify the precise reason for the job losses. For example, the commission noted in its decision to award Spain EUR 10 million from the European Globalization Adjustment Fund in 2008 that, 'the production of motor vehicle components were relocated to the tax free zone of Tangier (Morocco). This materialized in a Memorandum of Understanding signed the day after the closure of the Delphi factory in Puerto Real (Spain) between Delphi (USA) and the Government of Morocco' (EC 2008, 2). I code the 1,521 jobs lost as a result of the plant closure as being due to offshoring. ${ }^{28}$ However, some of the job losses were unrelated to offshoring. For example, Spain received EGF funds for redundancies in industries producing construction materials, such as doors and marble floor tiles. These job losses were the result of the 2008 global financial crisis' impact on Spain's construction industry, which suffered as the rate of new homes being built fell steeply. I coded these job losses as occurring for reasons other than offshoring.

As before, I used a difference-in-differences estimation strategy to estimate the average treatment effect on the treated. I consider national parliamentary elections in year $t=(2008,2011)$ because the EGF became operational in 2007 and its eligibility criteria remained constant over the entire period from 2008 to 2011. In 2011, the incumbent government party was the left-leaning Spanish Socialist Workers' Party (Partido Socialista Obrero Espanol, PSOE). I examined the PSOE's vote shares in national parliamentary elections for $i=(1, \ldots, 51)$ provinces. ${ }^{29}$ For each province, I calculated the number of job losses that occurred due to offshoring and the number of job losses that occurred for other reasons between the 2008 and 2011 elections. The results are reported in Table 3.

While job losses due to offshoring significantly reduced the incumbent government party's vote share, job losses for other reasons did not. This distinction holds when the number of

\footnotetext{
${ }^{28}$ This case is not included in the sample because it occurred before the 2008 election.

${ }^{29} \mathrm{I}$ use provinces as my unit of analysis here because all of the job losses reported in EGF applications between 2008 and 2011 for Catalonia were due to offshoring. In order to be able to compare the varied effects of different types of job losses on incumbent vote shares, I must therefore move beyond Catalonia to the nation as a whole.
} 
Table 3. Effect of different types of job losses on incumbent vote shares, by province, 2008-2011

\begin{tabular}{lccccc}
\hline Dependent variable = PSOE vote share & 1 & 2 & 3 & 4 & 5 \\
\hline Offshored job losses & -0.003 & & -0.003 & -0.003 & -0.003 \\
& $(0.0004)$ & & $(0.0005)$ & $(0.0005)$ & $(0.0005)$ \\
Other job losses & & 0.001 & 0.001 & 0.001 & 0.001 \\
& & $(0.003)$ & $(0.003)$ & $(0.003)$ & $(0.003)$ \\
Post period & -14.76 & -14.89 & -14.77 & -14.79 & -14.85 \\
& $(0.356)$ & $(0.373)$ & $(0.370)$ & $(0.428)$ & $(0.715)$ \\
Population (thousands) & & & & 0.001 & 0.001 \\
& & & & $(0.003)$ & $(0.003)$ \\
Economic growth rate & & & & -0.014 \\
& & & & $(0.119)$ \\
Intercept & 43.47 & 43.47 & 43.47 & 42.83 & 42.89 \\
Observations & $(0.169)$ & $(0.175)$ & $(0.170)$ & $(2.742)$ & $(2.692)$ \\
$R^{2}$ & 104 & 104 & 104 & 104 & 104 \\
\end{tabular}

Note: robust standard errors in parentheses.

offshored jobs is included in models by itself and also when it is included with the number of jobs lost for other reasons. In this sample, the average number of job losses from offshoring in a treated province was 523. An offshoring-induced loss of 523 jobs reduces the incumbent's vote share by 1.6 percentage points, on average. This sized vote loss is equivalent to a 5.6 per cent reduction in the PSOE's total vote share in 2011.

While offshored jobs reduced the incumbent's vote share, jobs lost for other reasons did not. The point estimate on the intensity of treatment variable equal to the number of jobs lost for other reasons is close to zero and fails to reach conventional levels of statistical significance in any of the estimated models. The large standard errors may reflect the fact that voters react differently to different types of job losses.

These results are consistent with findings from the United States. Margalit (2011) found that layoffs due to offshoring were correlated with a reduction in the incumbent president's vote shares between the 2000 and 2004 elections. Yet job losses caused by other forms of international competition, such as imports, were not. It is striking that similar results emerge in two different settings: presidential elections in the United States and parliamentary elections in Spain. In both settings, offshoring-related job losses engendered a larger anti-incumbent vote than job losses due to other international sources. These results are also broadly consistent with findings reported by Di Tella and Rodrik (2020). In a survey conducted in the United States, they found that job losses due to offshoring elicited greater demand for government action than job losses due to other factors.

What else might explain voters' varied reactions to different types of job losses? The findings reported in Table 3 rule out one possible explanation, namely varied government responses to job losses from different sources. Having ruled out government policy as a potential answer, the question remains: why do voters appear to punish incumbents more severely for offshoring-induced job losses than for other types of job losses? I offer four possible suggestions here, but leave the task of investigating their relative explanatory power to future research.

First, voters may view offshoring as a preventable loss, whereas job losses from other sources, such as a mismanaged company, are not. Because governments can (and do) provide firms with generous economic incentives to keep jobs onshore, voters may consequently view offshoring as a result of government inaction and vote against the incumbent government party in the subsequent election.

Secondly, the costs of job losses from offshoring may be higher than the costs of job losses from other sources. Offshored workers typically have a different age and/or skill profile than other unemployed persons. In Spain, for example, workers who were unemployed because of 
offshoring in the textile industry were mostly women, and were often middle-aged with relatively low qualifications (Miguélez Lobo 2004). The possibility of retraining to obtain jobs under similar conditions was limited. To obtain new jobs after theirs moved abroad, many workers had to accept worse pay or temporary jobs (Miguélez Lobo 2004). If offshored workers face relatively higher costs from becoming unemployed, then government compensation may fail to appease them at the same rate it does for other citizens who lost their jobs for different reasons.

Thirdly, different types of job losses may have varied labor market effects. If production moves to a new location within a country, rather than abroad, suppliers may continue to exist. As a result, fewer jobs will be lost when a plant relocates production to a different part of the country, as compared to a foreign country. Furthermore, jobs that move abroad are not coming back, while those that move to a different part of the country are 'recoverable'. People can follow the production by moving to a different part of the country and seeking re-employment. This may help explain why twice as many respondents identified offshoring as an event that would make them less likely to vote for the incumbent than the closure of a local business to move to a different part of Spain.

Finally, the media's coverage of offshoring may elicit a disproportionate voter reaction. When covering offshoring, the media often explicitly identifies foreign competition as the cause of the job losses and sometimes even names a specific foreign country (Margalit 2011, 184). In 90 per cent of the cases in my sample, I could identify the country to which production was moving from media reports alone. ${ }^{30}$ The fact that offshoring is closely associated with 'others' may trigger voters' nationalism and/or ethnocentrism (for example, Mansfield and Mutz 2013; Margalit 2011). While a perception that foreigners are taking away 'our jobs' may stir nationalist or ethnocentric sentiments, it is not obvious why this would necessarily lead to an anti-incumbent vote. Further research is needed to explore this and other potential mechanisms that may uniquely link offshoring to anti-incumbent voting.

\section{Conclusion}

Offshoring is one of the most controversial aspects of modern-day globalization. Yet to date, it has been unclear how it impacts democratic elections. Understanding the political consequences of offshoring is an important and timely objective because it is poised to become an ever more urgent issue for elected leaders as technology facilitates the move of high-skilled jobs abroad. Covid-19 may further accelerate offshoring. Many firms adopted remote working practices following the outbreak of the pandemic. The move to widespread virtual interactions removed geography as a limiting constraint, and jobs that can be done remotely can also be done offshore (Mancl and Fraser 2020). The coronavirus may consequently spur a new, more virulent, wave of offshoring (Borrett 2020).

Using novel data on offshoring and a difference-in-differences estimation strategy, I found that voters punish the political parties in government when businesses move production abroad. Incumbent government parties lose more votes in municipalities where a plant relocates production abroad between elections than in municipalities that do not experience such an event. This result holds for different elections, in different years, for different incumbent parties and at different levels of government. In both national and sub-national elections, voters punish incumbent government parties for offshoring, and parties' vote shares fall as the number of jobs lost due to offshoring increases. In multiparty coalition governments, voters disproportionately punish the largest party in government for offshoring. Incumbent government parties of various ideological stripes lose more votes in municipalities where production relocated internationally between elections than in those that did not experience such an event.

\footnotetext{
${ }^{30}$ The most frequent destination was China, followed by Eastern Europe (i.e., Romania, Hungary, Czech Republic and Poland).
} 
These results are striking because they emerge in Spain - a country with party-centered electoral competition, multi-member districts, closed-party lists and PR electoral rules. Proportional electoral rules improve representation, but generally do so at the expense of accountability (Lijphart 1984; Lijphart 2012; Powell 2000). Accountability exists when there is: (1) clarity of responsibility for political outcomes and (2) voters can effectively sanction those responsible for the outcomes (Powell 2000). Plurality electoral systems tend to score highly on these two criteria, while PR systems do less well. Yet even in a closed-list PR system like Spain, I find that voters punish incumbent government parties for offshoring.

These results are unlikely to be unique to the Spanish context. In fact, Spain arguably represents a 'least likely' case because it has some of the toughest employment protection regulations in the developed world (for example, Levy 2007; Odell 2001). Spanish labor law makes it difficult for firms to lay off workers, and workers who are laid off receive generous compensation. Unemployed workers have the right to a minimum severance payment equivalent to 20 days of salary per year of service; in practice, higher severance payments are usually agreed. Unemployed persons can also take advantage of Spain's generous active labor market policies, which include retraining and relocation assistance (OECD 2007). These programs help protect Spanish workers from the costs of offshoring. As a result, voters in Spain may not punish incumbents as severely for offshoring as those in countries with less generous compensation programs. ${ }^{31}$ Empirically assessing the generalizability of the results of this study is an important task for future research.

Economic globalization has significant implications for politics and, as this study shows, these implications extend beyond the United States to democracies with other types of electoral institutions, such as Spain. It is striking that offshoring decisions taken by multinational corporations headquartered in foreign countries can influence elections in high-functioning, consolidated democracies. This finding suggests that, in today's era of globalization, all politics are indeed global.

Supplementary material. Online appendices are available at https://doi.org/10.1017/S0007123420000757.

Acknowledgements. I am grateful for the helpful feedback I received on this project from José Fernández-Albertos, Bonnie Field, Jeff Frieden, Farsan Ghassim, Judy Goldstein, Nate Jensen, Noel Johnston, Cova Meseguer, Erica Owen, Gerard Padró i Miquel, Didac Queralt, Dennis Quinn, Andrea Ruggeri, Maria Sánchez-Vidal, and seminar participants at the Carlos III-Juan March Institute of Social Sciences, Harvard University, New York University Abu Dhabi, Oxford University, the Spanish National Research Council (CSIC), Stanford University, the University of California Riverside, and Yale University. Thank you also to participants who commented on the article at the 2018 Annual Meeting of the International Political Economy Society and the 2019 Annual Meeting of the American Political Science Association.

Data availability statement. Replication data for this article can be found in Harvard Dataverse at: https://doi.org/10.7910/ DVN/X1JL2H

\section{References}

Alkon M (2017) Local Sociotropism: How Community Variation in Trade Exposure Affects Voter Demands. Available from https://ssrn.com/abstract=3103852 or http://dx.doi.org/10.2139/ssrn.3103852.

Amiti M and Wei S-J (2009) Does service offshoring lead to job losses? Evidence from the United States. In M Reinsdorf and MJ Slaughter (eds), International Trade in Services and Intangibles in the Era of Globalization. Chicago, IL: University of Chicago Press, pp. 227-243.

Anderson CJ (2007) The end of economic voting? Contingency dilemmas and the limits of democratic accountability. Annual Review of Political Science 10, 271-296.

Ansolabehere S, Meredith M and Snowberg E (2014) Mecro-economic voting: local information and micro-perceptions of the macro-economy. Economics \& Politics 26(3), 380-410.

Ashworth S (2012) Electoral accountability: recent theoretical and empirical work. Annual Review of Political Science 15, 183-201.

\footnotetext{
${ }^{31}$ The fact that voters punish incumbents for offshoring despite Spain's generous unemployment programs raises questions about the efficacy of compensation for offsetting the costs of globalization. On this point, see Rickard (2019).
} 
Bachmann R and Braun S (2011) The impact of international outsourcing on labour market dynamics in Germany. Scottish Journal of Political Economy 58(1), 1-28.

Bali VA (2007) Terror and elections: lessons from Spain. Electoral Studies 26(3), 669-687.

Besley T (2006) Principled Agents? The Political Economy of Good Government. Oxford University Press on Demand. Doi:10.1093/acprof:oso/9780199283910.001.0001

Biscourp P and Kramarz F (2007) Employment, skill structure and international trade: firm-level evidence for France. Journal of International Economics 72(1), 22-51.

Borrett A (2020) WFH today, offshoring tomorrow? Why Covid-19 may accelerate the globalisation of work, Tech Monitor, 2 November. Available from https://techmonitor.ai/boardroom/workforce/covid-19-accelerate-globalisation-of-work.

Bronfenbrenner K and Luce S (2004) Offshoring: the evolving profile of corporate global restructuring. Multinational Monitor 25(12), 26.

Broz L, Frieden J and Weymouth S (2019) Populism in place: the economic geography of the globalization backlash. Unpublished Manuscript.

Chase KA (2008) Moving Hollywood abroad: divided labor markets and the new politics of trade in services. International Organization 62(4), 653-687.

Colantone I and Stanig P (2018) The trade origins of economic nationalism: import competition and voting behavior in Western Europe. American Journal of Political Science 62(4), 936-953.

Cramer KJ (2016) The Politics of Resentment: Rural Consciousness in Wisconsin and the Rise of Scott Walker. Chicago, IL: University of Chicago Press.

Dean A and Kimmel S (2019) Free trade and opioid overdose death in the United States. SSM-Population Health 8, 100409.

Di Tella R and Rodrik D (2020) Labour market shocks and the demand for trade protection: evidence from online surveys. The Economic Journal 130(628), 1008-1030.

Dorn D, Hanson G and Majlesi K (2020) Importing political polarization? The electoral consequences of rising trade exposure. American Economic Review 110(10), 3139-83.

Duch R and Stevenson R (2008) The Economic Vote: How Political and Economic Institutions Condition Election Results. Cambridge: Cambridge University Press.

Duch R and Stevenson R (2013) Voter perceptions of agenda power and attribution of responsibility for economic performance. Electoral Studies 32(3), 512-516.

Ebenstein A et al. (2014) Estimating the impact of trade and offshoring on American workers using the current population surveys. The Review of Economics and Statistics 96(4), 581-595.

Eisen EA et al. (2020) Suicide, overdose and worker exit in a cohort of Michigan autoworkers. Journal of Epidemiology \& Community Health. Available from https://jech.bmj.com/content/74/11/907 (accessed 4 January 2020).

European Commission (2005) Social values, science and technology. Eurobarometer Special Report 225.

European Commission (2008) Proposal for a Decision of the European Parliament and of the Council on the Mobilisation of the European Globalisation Adjustment Fund (presented by the Commission). Brussels: European Commission.

Feigenbaum JJ and Hall A (2015) How legislators respond to localized economic shocks: evidence from Chinese import competition. The Journal of Politics 77(4), 1012-1030.

Feler L and Senses MZ (2017) Trade shocks and the provision of local public goods. American Economic Journal: Economic Policy 9(4), 101-143.

Fernández-Albertos J, Kuo A and Balcells L (2013) Economic crisis, globalization, and partisan bias: evidence from Spain. International Studies Quarterly 57(4), 804-816.

Field BN (2016) Why Minority Governments Work: Multilevel Territorial Politics in Spain. New York: Palgrave Macmillan.

Fortunato D and Stevenson R (2013) Performance voting and knowledge of cabinet composition. Electoral Studies 32(3), 517-523.

Frieden J (2018) The Politics of the Globalization Backlash: Sources and Implications. Prepared for Presentation at the Annual Meeting of the American Economics Association.

Görg H and Hanley A (2005) Labour demand effects of international outsourcing: evidence from plant-level data. International Review of Economics \& Finance 14(3), 365-376.

Healy A and Malhotra N (2013) Retrospective voting reconsidered. Annual Review of Political Science 16, 285-306.

Hellwig T (2001) Interdependence, government constraints, and economic voting. The Journal of Politics 63(4), 1141-1162.

Hellwig T (2014) Globalization and Mass Politics: Retaining the Room to Maneuver. Cambridge: Cambridge University Press.

Helpman E (1984) A simple theory of international trade with multinational corporations. Journal of Political Economy 92 (3), 451-471.

Hierro MJ and Queralt D (2021) The divide over independence: explaining preferences for secession in an advanced open economy. American Journal of Political Science. Doi: 10.1111/ajps.12549.

Hobolt S, Tilley J and Banducci S (2013) Clarity of responsibility: how government cohesion conditions performance voting. European Journal of Political Research 52(2), 164-187.

Holl A (2004) Manufacturing location and impacts of road transport infrastructure: empirical evidence from Spain. Regional Science and Urban Economics 34(3), 341-363. 
Hummels D et al. (2014) The wage effects of offshoring: evidence from Danish matched worker-firm data. American Economic Review 104(6), 1597-1629.

Jensen JB, Quinn DP and Weymouth S (2017) Winners and losers in international trade: the effects on US presidential voting. International Organization 71(3), 423-457.

Jensen NM and Malesky EJ (2018) Incentives to Pander: How Politicians Use Corporate Welfare for Political Gain. Cambridge and New York: Cambridge University Press.

Jofre-Monseny J, Sánchez-Vidal M and Viladecans-Marsal E (2018) Big plant closures and local employment. Journal of Economic Geography 18(1), 163-186.

Kayser MA (2007) How domestic is domestic politics? Globalization and elections. Annual Review of Political Science 10, 341-362.

Kayser MA and Peress M (2012) Benchmarking across borders: electoral accountability and the necessity of comparison. American Political Science Review 106(3), 661-684.

Kiewiet DR and Lewis-Beck MS (2011) No man is an island: self-interest, the public interest, and sociotropic voting. Critical Review 23(3), 303-319.

Koeber C and Wright DW (2001) W/age bias in worker displacement: how industrial structure shapes the job loss and earnings decline of older American workers. The Journal of Socio-Economics 30(4), 343-352.

León S (2014) How does decentralization affect electoral competition of state-wide parties? Evidence from Spain. Party Politics 20(3), 391-402.

Levy JS (2007) Qualitative methods and cross-method dialogue in political science. Comparative Political Studies 40(2), $196-214$.

Lewis-Beck MS and Stegmaier M (2000) Economic determinants of electoral outcomes. Annual Review of Political Science 3 (1), 183-219.

Lijphart A (1984) Advances in the comparative study of electoral systems. World Politics 36(3), 424-436.

Lijphart A (2012) Patterns of Democracy: Government Forms and Performance in Thirty-six Countries. New Haven, CT: Yale University Press.

Lü X, Scheve K and Slaughter MJ (2012) Inequity aversion and the international distribution of trade protection. American Journal of Political Science 56(3), 638-654.

Mancl D and Fraser SD (2020) COVID-19's influence on the future of agile. In International Conference on Agile Software Development. Cham: Springer, pp. 309-316.

Mansfield ED and Mutz DC (2009) Support for free trade: self-interest, sociotropic politics, and out-group anxiety. International Organization 63(3), 425-457.

Mansfield ED and Mutz DC (2013) US Versus them: mass attitudes toward offshore outsourcing. World Politics 65(4), 571-608.

Margalit Y (2011) Costly jobs: trade-related layoffs, government compensation, and voting in US elections. American Political Science Review 105(1), 166-188.

Margalit Y (2013) Explaining social policy preferences: evidence from the Great Recession. American Political Science Review 107(1), 80-103.

Margalit Y (2019) Political responses to economic shocks. Annual Review of Political Science 22, 277-295.

Martin S (2018) Bargaining in legislatures, portfolio allocation, and the electoral costs of governing. West European Politics 41(5), 1166-1190.

Michael B and Michael R (2012) Outsourcing: mass layoffs and displaced workers' experiences. Management Research Review 35(11), 1029-1045.

Miguélez Lobo F (2004) Company relocations cause concern. Dublin: Eurofound. Available from https://www.eurofound. europa.eu/sr/observatories/eurwork/articles/company-relocations-cause-concern (accessed 28 June 2018).

Montalvo JG (2011) Voting after the bombings: a natural experiment on the effect of terrorist attacks on democratic elections. Review of Economics and Statistics 93(4), 1146-1154.

Myro-Sánchez R and Fernández-Otheo CM (2008) Profitability of Spanish foreign direct investment. Journal of Globalization, Competitiveness \& Governability/Revista de Globalización, Competitividad y Gobernabilidad/Revista de Globalização, Competitividade e Governabilidade 2(3), 76-99.

Odell JS (2001) Case study methods in international political economy. International Studies Perspectives 2(2), 161-176.

OECD (2007) Offshoring and Employment: Trends and Impacts. Paris: Organisation for Economic Co-operation and Development.

Owen E (2017) Exposure to offshoring and the politics of trade liberalization: debate and votes on free trade agreements in the US House of Representatives, 2001-2006. International Studies Quarterly 61(2), 297-311.

Owen E (2018) Foreign direct investment and elections: the impact of greenfield FDI on incumbent party reelection in Brazil. Comparative Political Studies 52(4), 613-635.

Owen E and Johnston NP (2017) Occupation and the political economy of trade: job routineness, offshorability, and protectionist sentiment. International Organization 71(4), 665-699.

Powell GB (2000) Elections as Instruments of Democracy: Majoritarian and Proportional Visions. New Haven, CT: Yale University Press. 
Powell GB and Whitten GD (1993) A cross-national analysis of economic voting: taking account of the political context. American Journal of Political Science 37, 391-414.

Queralt D (2012) Economic voting in multi-tiered polities. Electoral Studies 31(1), 107-119.

Rickard SJ (2012) Electoral systems, voters' interests and geographic dispersion. British Journal of Political Science 42(4), 855-877.

Rickard SJ (2018) Spending to Win: Political Institutions, Economic Geography, and Government Subsidies. Cambridge: Cambridge University Press.

Rickard SJ (2019) Globalization, Compensation, and the Rise of the Far Right. Prepared for Presentation at the Annual Meeting of the International Political Economy Society.

Rickard SJ (2020) Replication Data for: Incumbents beware: the impact of offshoring on elections, https://doi.org/10.7910/ DVN/X1JL2H, Harvard Dataverse, V1.

Riera P (2013) Voting differently across electoral arenas: empirical implications from a decentralized democracy. International Political Science Review 34(5), 561-581.

Rodden J and Wibbels E (2011) Dual accountability and the nationalization of party competition: evidence from four federations. Party Politics 17(5), 629-653.

Rodon T and Guinjoan M (2018) When the context matters: identity, secession and the spatial dimension in Catalonia. Political Geography 63, 75-87.

Rodrik D (2011) The Globalization Paradox: Why Global Markets, States, and Democracy Can't Coexist. Oxford: Oxford University Press.

Rommel T and Walter S (2018) The electoral consequences of offshoring: how the globalization of production shapes party preferences. Comparative Political Studies, 55(5), 621-658.

Samuels D and Hellwig T (2010) Elections and accountability for the economy: a conceptual and empirical reassessment. Journal of Elections, Public Opinion and Parties 20(4), 393-419.

Cite this article: Rickard SJ (2022). Incumbents Beware: The Impact of Offshoring on Elections. British Journal of Political Science 52, 758-780. https://doi.org/10.1017/S0007123420000757 